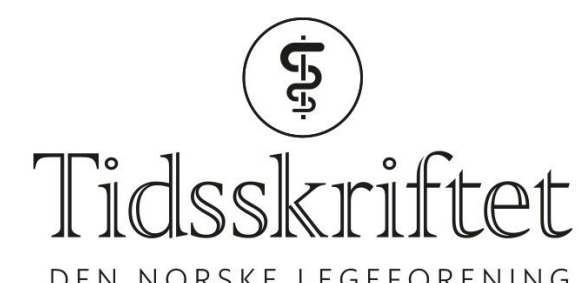

DEN NORSKE LEGEFORENING

\title{
Den tredje Eyr
}

MINILEDER

ARE BREAN

Sjefredaktør

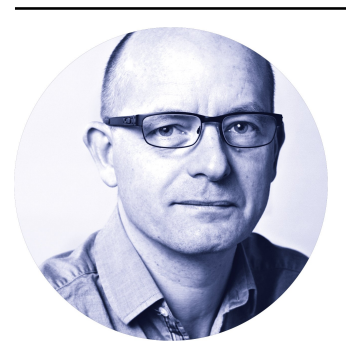

I 21 år har Eyr vært norske allmennlegers viktigste diskusjonsforum. Men nå er det slutt. Den umodererte e-postlisten ga mindre og mindre nytte for deltagerne. Hogne Sandvik, som har vært ansvarlig for listen siden starten i 1996, ble også den som la den ned.

På mange måter er utviklingen naturlig. Tiden har løpt fra e-postlister som diskusjonsforum. Sosiale medier som Facebook og Twitter har overtatt mange av de samme funksjonene. Det har også nettbaserte kommentarfelt i Tidsskriftet og andre medier.

Men Eyr har vært viktig. Listen har knyttet sammen et geografisk spredt allmennlegekorps. Og den har påvirket helsepolitikken. Helt fra da et kollektivt utformet brev på Eyr i 1997 utløste lovregulering av forsikringsselskapenes tilgang til helseopplysninger, og til fastlegeaksjonens protestbrev til helseministeren i 2012, har Eyr vist at grasrotaksjon utgjør en forskjell. Den erfaringen er nyttig å ta med videre til nye medier.

Den første Eyr var gudinne for legekunst i norrøn mytologi. Den andre Eyr var Norges første medisinske tidsskrift, utgitt i årene 1826-1837. Nå går den tredje Eyr inn i historien. I likhet med de to første har også denne vært barn av sin tids syn på legekunst og helsestell. De mange titusener av meldinger fra Eyr som nå deponeres i Nasjonalbiblioteket, vil bli en skattkiste for fremtidens helsehistorikere.

Publisert: 28. november 2017. Tidsskr Nor Legeforen. DOI: 10.4045/tidsskr.17.22.01

(C) Tidsskrift for Den norske legeforening 2020. Lastet ned fra tidsskriftet.no 